\title{
Evaluation of Solar Disinfection of water intervention delivered through Lady Health Workers in reduction of diarrheal episodes in under five children
}

\author{
Shabina Ariff', Ubaidullah Khan ${ }^{2}$, Ali Turab ${ }^{1}$, Imtiaz Hussain ${ }^{1}$, Atif Habib ${ }^{1}$, Tarab Mansoor ${ }^{1}$, Dania \\ Mallick $^{1}$, Zamir Suhag ${ }^{1}$, Zaid Bhatti ${ }^{1}$, Imran Ahmed ${ }^{1}$, Sajid Bashir Soofi ${ }^{1 *}$, Zulfiqar A Bhutta ${ }^{3,4}$ \\ ${ }^{1}$ Department of Pediatrics \& Child Health, Aga Khan University, Karachi, Pakistan \\ ${ }^{2}$ Department of Pediatrics, King Edward Medical University, Lahore, Pakistan \\ ${ }^{3}$ Center of Excellence in Women and Child Health, Aga Khan University, Karachi, Pakistan \\ ${ }^{4}$ Center for Global Child Health, Hospital for Sick Children, Toronto, Canada
}

Received: June 13, 2016; Accepted: June 20, 2016; Published: June 28, 2016

*Corresponding author: Dr. Sajid Bashir Soofi, Associate Professor, Department of Pediatrics \& Child Health, Aga Khan University, Stadium Road, Karachi-74800, Pakistan, Tel:+92-300-2769398;Phone: +92-21-34864798;E-mail: sajid.soofi@aku.edu

\begin{abstract}
Background: Solar Water Disinfection (SODIS) is a simple, inexpensive and sustainable means of daily household treatment for drinking and storage of water. Globally, over a billion people lack access to safe drinking water. As many as half million under five children die annually due to diarrheal illnesses. Most of these deaths are concentrated in Africa and South Asia. Unsafe water is one of the most critical risk factors for diarrhoea. Systematic reviews indicate that interventions to improve the microbial quality of drinking water in households are effective at reducing diarrhoea illnesses and thereby contribute significantly in reducing deaths due to communicable diseases in children under 5 years. We evaluated the impact of the SODIS intervention on health outcomes and diarrheal episodes in two districts of Punjab province in Pakistan.
\end{abstract}

Methods: A cross-sectional survey was undertaken to assess the impact of solar water disinfection (SODIS) program in two districts of Punjab province, Pakistan. The program was implemented by the Ministry of Health from April 2010- May 2011 in Faisalabad district. We selected Toba Tek Singh as a comparison district for the survey.

Results: Analysis with regression models revealed that children had a lower risk of contracting diarrhoea when they consumed high percentages of safe drinks (SODIS), lived in households with good hygiene, washed hands, and belonged to the richest quintile. Diarrhoea prevalence was 10.1 episodes per child per year in the non-intervention area compared to 5.6 episodes per child per year ( $<$ $0.0001)$ in the intervention area. Similarly the proportion of children with dysentery reported in the intervention was half compared to non-intervention area (6.1\% vs. $13.9 \%)$. SODIS method for purifying drinking water is acceptable and effective in the developing countries. It should be a part of preventive strategies at health system level to control diarrheal illnesses and reduce under five mortality.

Keywords: SODIS; Solar water disinfection; Diarrhea; Lady health worker(LHW)

\section{Background}

Elimination of waterborne illnesses alone can add up to two years to the life expectancy at birth in Pakistan (1). As many as 6 million children under the age of five die annually, quarter of these deaths are attributable to environmental factors and 0.6 million die due to diarrheal illnesses (2-4). Approximately $79 \%$ of these deaths are concentrated in Africa and South Asia [2] Unsafe water, sanitation, and hygiene are rendered as the most critical global risk factors for diarrhoea and related illnesses [5].Globally, over 1.1 billion people lack of access to safe drinking water and are at risk of becoming infected with water-related pathogens [6]

In Pakistan, only $49 \%$ of rural population has access to improved drinking water source (tube well, bore hole) and 91\% do not treat drinking water in any way prior to consumption [7]. These numbers reflect the need to restructure our efforts, strategies, and interventions if we are to narrow the gap towards reaching the Sustainable Development Goals 2030.Construction of water supply schemes and treatment plants as well as sanitation and waste management requires significant resources and planning. However household treatment methods such as chlorination, filtration, flocculation and solar disinfection have emerged as effective and inexpensive alternative in places where access to safe piped water is not available.

Systematic reviews indicate that interventions to improve the microbial quality of drinking water in households are effective at reducing diarrhoea illnesses and thereby contribute significantly in reducing deaths due to communicable diseases in children under 5 years [8-10]. Trials carried out in Africa, India and Caribbean islands have shown solar disinfection could serve as a low cost simple and effective alternative method of water purification at household level [11-13]. Disposable translucent plastic bottles in which pathogen containing water is purified by the combined pathogen- inactivating effects of solar radiation 
and heating $[14,15]$. SODIS is proven efficacious by laboratory improving the quality of water [15-17]. Its use is advocated in developing countries to improve health in settings where safe drinking water is not available. Despite the efforts only a few field studies assessed its health impact and evidence on acceptance, regular use, and scalability of the method is scarce and inconclusive [18-23].

Unfortunately there are no local studies to validate regional outcomes, especially in context to its acceptability in the rural community where majority of the population resides. Our study attempted to evaluate, and measure the health outcomes of solar water disinfection (SODIS) and its acceptability in Faisalabad and Toba Tek Singh districts of Punjab province Pakistan.

\section{Material and Methods}

We carried out an impact assessment of solar water disinfection (SODIS) program through a cross-sectional survey in two districts (Faisalabad, Toba Tek Singh) Punjab, Pakistan

\section{Implementation of Intervention}

SODIS intervention was introduced and implemented by Community Action Program (CAP), an initiative taken by the Ministry of Health Pakistan through the Lady Health Workers (LHW's) of the National Program of Family Planning and Primary Health Care from April 2010-May 2011. The LHW's are community health workers employed by the Ministry of Health. At present there are $\sim 100,000$ LHWs that provide an essential link between the formal health system and the communities. They provide antenatal care, postnatal visits for the mother and newborn, immunization services, and health education on hygiene and sanitation.

Faisalabad served as the intervention district where SODIS was implemented along with community mobilization and awareness messages on diarrheal disease prevention and hygiene. Community mobilization involved formation of village health committees (VHCs) and Self-help Groups (SHGs) through LHWs / CHWs and key influential people to create sensitization on SODIS. Regular monthly meetings were held for advocacy of SODIS as a simple method of water purification by CHW. Brochures and pamphlet with pictorials in local language were used for this purpose.

Toba Tek Singh was selected as anon-intervention district. Faisalabad stands in the rolling flat plains of northeast Punjab and is a major industrial centre in the heart of Pakistan with a population that is a blend of agrarian and industrial urban populace. The population of Faisalabad city is 1.23 million Toba Tek Singh is a neighboring district with a population of 1.39 million.

\section{Data Collection}

To exclude any possible bias the data collection was carried out by an independent team of data collectors living in the same locality who were not involved in any of the project activities .There were 5 teams of data collectors, each team comprising of 3 data collectors and one male supervisor. The data collectors received a 3 day class room training on the content of the questionnaire and its administration prior to the initiation of the survey.

The cross sectional survey was conducted from May - June, 2011 after one year of the intervention implementation. The target population was mothers with children under five years of age. All mothers whose children had diarrhoea in the two weeks prior to the date of the interview and in the last 24 hours were enrolled A verbal consent was sought prior to the administration of data collection questionnaire.

The questionnaire sought information on health, hygiene, water management habits, knowledge, practices and perceptions about diarrheal illnesses, water sterilization, and disinfection practices including SODIS methods.

Diarrhoea was defined as per WHO 'the passage of three or more loose or liquid stools per day (or more frequent passage than is normal for the individual)'. A new episode of diarrhea was considered if there was a 3 day asymptomatic period between consecutive 2 episodes. Dysentery was defined as presence of blood /mucus in stools.

\section{Sampling Frame}

The WHO's "30 x 7" cluster sampling method was adopted. The catchment population of one LHW served as a cluster. Typically a LHW's catchment area is comprised of approximately of 150 to 200 households. Thirty clusters were randomly selected from both intervention and control areas. Systematic sampling technique was used to select households from each selected cluster. In case the response from selected household could not be attained (no child less than 5 years, or temporarily not at home due to family vacation or any emergency) substitution of sampled household was allowed by selecting subsequent household using the "next nearest household" approach. Household with women having at least one child less than five years of age was selection criteria. If there was more than one eligible woman in a household, then only one of them was selected randomly.

\section{Ethical Clearance}

The study was approved by Ethical Review Committee of Aga Khan University. Informed consent was sought from each respondent before inclusion into the study. Confidentiality of data was maintained throughout the study and was only accessible to the senior project staff. Participants in the study were allocated unique ID number for identification.

\section{Quality Assurance}

The quality of data was ensured through review meetings and supervisory field visits. A random $5 \%$ of interviews were also attended by the study supervisor. The purpose of these visits was to ensure if correct interview procedure and probing techniques were being applied by the interviewers. Daily progress report was generated by the data management unit and the supervisor conducted daily debriefing meetings for problems pertaining to interviews and operations. Random field visits were undertaken by study investigators to ensure quality and adequacy of collected data. 


\section{Statistical Methods and Analysis}

For data entry, the entry screens were developed in Microsoft visual FoxPro version 7.0. The data entry screens employed range and logical checks to identify and manage erroneous values. All the data were dual entered. The statistical analysis was performed by using SPSS version 19. Frequency and percentages were reported for categorical variables and mean and standard deviations for quantitative variables. Proportions were tested by using chi-square across the control and intervention arm. Independent sample t-test was used to calculate the mean difference between the two arms for quantitative variables with a level of significance at $5 \%$. Differences in the diarrhoea frequency between the intervention and control groups were determined through the risk rate as well as through the difference between the risk rates as a function of safe/unsafe water consumption.

Bivariate analyses of factors associated with diarrheal prevalence were tested using binary logistic regression. Variables with $\mathrm{p}$ value $<0.25$ in the bivariate analysis were considered for inclusion in the multivariable logistic regression model. A parsimonious model building strategy was used to select variables with statistical significance on multivariable analysis.
Unadjusted and adjusted odds ratios were presented.

\section{Results}

Total 2,792 household participated in the study; 1,391 interviews were conducted in the intervention and 1,401 in the control arm. Demographic, socioeconomic characteristics and wash practices of the population are described in Table 1 . The base line household characteristics and demographics were comparable in both areas. Majority of household in both areas used electric motor pumps to access underground water for drinking purposes similarly, toilet facility and waste disposal scenario at both the areas was dominated by pour flush and connected sewer. Almost 93\% respondents in intervention and $87 \%$ in control arms reported that their under 5 children washed hands more than three times a day. Similarly the use of soap for hand washing was significantly high but comparable in the intervention (98.5\%) and control areas $(92.9 \% \mathrm{p}<0.0001)$. However the proportion of household who reported Lady Health Worker (LHW) as the main source of information on health and hygiene practices was substantially higher in the intervention area (88.9) compared to control (29.4).

Table 1: Demographics, socio economic \& wash practices.

\begin{tabular}{|c|c|c|c|}
\hline & $\begin{array}{c}\text { Faisalabad } \\
\text { (Intervention) }\end{array}$ & $\begin{array}{l}\text { Toba Tek Singh } \\
\text { (Control) }\end{array}$ & p-value \\
\hline Total Household participated in the study & 1391 & 1401 & \\
\hline Total population & 7639 & 7902 & \\
\hline M:F ratio & 1.01 & 0.98 & \\
\hline Household density & 5.49 & 5.64 & \\
\hline Under 5 population out of total population $\mathbf{n}(\%)$ & $2213(29)$ & $2429(30.7)$ & \\
\hline Total Male - under 5 & 1165 & 1201 & \\
\hline Total Female- under 5 & 1048 & 1228 & \\
\hline Literacy rate (over $10+$ years age) $\mathbf{n}(\mathbf{~} \%)$ & 2949 (69.2) & $2831(65.6)$ & \\
\hline $\begin{array}{c}\text { Ownership status of the house } \mathbf{n}(\%) \\
\text { Owned } \\
\text { Rented } \\
\text { Living without paying rent }\end{array}$ & $\begin{array}{l}1348(96.9) \\
27(1.9) \\
16(1.2)\end{array}$ & $\begin{array}{l}1338(95.5) \\
29(2.1) \\
34(2.4)\end{array}$ & \\
\hline $\begin{array}{c}\text { Number of rooms in the house } \mathbf{n}(\mathbf{\%}) \\
1 \\
2 \\
\geq 3 \\
\text { Mean } \pm \text { SD (rooms) }\end{array}$ & $\begin{array}{l}397(28.5) \\
510(36.7) \\
484(34.8) \\
2.34 \pm 1.36\end{array}$ & $\begin{array}{l}535(38.2) \\
534(38.1) \\
332(23.7) \\
2.01 \pm 1.17\end{array}$ & \\
\hline $\begin{array}{c}\text { Fuel for cooking } \mathbf{n}(\%) \\
\text { Firewood } \\
\text { Gas } \\
\text { Others }\end{array}$ & $\begin{array}{c}697(50.1) \\
653(46.9) \\
41(2.9)\end{array}$ & $\begin{array}{c}715(51) \\
627(44.8) \\
59(4.2)\end{array}$ & \\
\hline $\begin{array}{c}\text { Electricity in the house n (\%) } \\
\text { No } \\
\text { Yes }\end{array}$ & $\begin{array}{c}6(0.4) \\
1385(99.6)\end{array}$ & $\begin{array}{c}10(0.7) \\
1391(99.3)\end{array}$ & \\
\hline $\begin{array}{c}\text { Main source of drinking water n (\%) } \\
\text { Tape/Pipe water } \\
\text { Hand Pump } \\
\text { Motor Pump } \\
\text { Tube Well } \\
\text { Others }\end{array}$ & $\begin{array}{l}263(18.9) \\
346(24.9) \\
564(40.5) \\
155(11.1) \\
63(4.5)\end{array}$ & $\begin{array}{l}259(18.5) \\
370(26.4) \\
549(39.2) \\
154(11) \\
69(4.9)\end{array}$ & \\
\hline
\end{tabular}




\begin{tabular}{|c|c|c|c|}
\hline $\begin{array}{l}\text { Toilet facility n (\%) } \\
\text { Pour Flush } \\
\text { Open Field } \\
\text { Pit Latrine }\end{array}$ & $\begin{array}{c}1358(97.6) \\
28(2) \\
5(0.4)\end{array}$ & $\begin{array}{c}1370(97.8) \\
27(1.9) \\
4(0.3)\end{array}$ & \\
\hline $\begin{array}{l}\text { Disposal of household waste } \mathbf{n}(\%) \\
\text { Sewer connected } \\
\text { Left Open } \\
\text { Buried } \\
\text { Others }\end{array}$ & $\begin{array}{l}1153(82.9) \\
82(5.9) \\
118(8.5) \\
38(2.7)\end{array}$ & $\begin{array}{l}1101(78.6) \\
38(2.7) \\
224(16) \\
38(2.7)\end{array}$ & \\
\hline $\begin{array}{l}\text { How many times do your children below } 5 \text { years wash their } \\
\text { hands per day? n (\%) } \\
1-2 \\
3+ \\
\mathrm{n}\end{array}$ & $\begin{array}{c}96(6.9) \\
1295(93.1) \\
1391\end{array}$ & $\begin{array}{c}188(13.4) \\
1213(86.6) \\
1401\end{array}$ & $<0.0001 \ddagger$ \\
\hline $\begin{array}{l}\text { When do your children below } 5 \text { years wash their hands? n (\%) } \\
\text { Before eating food } \\
\text { After toilet } \\
\text { At morning time only }\end{array}$ & $\begin{array}{c}1092(79.7) \\
1160(84.7) \\
194(14.2)\end{array}$ & $\begin{array}{l}978(75.1) \\
1054(81) \\
121(9.3)\end{array}$ & $\begin{array}{c}0.005 \ddagger \\
0.011 \neq \\
<0.0001 \ddagger\end{array}$ \\
\hline 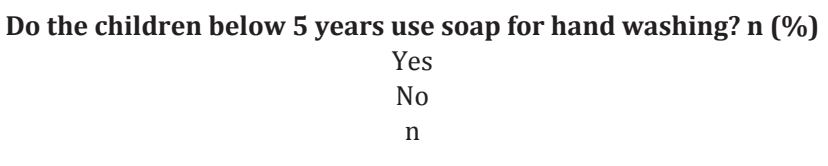 & $\begin{array}{c}1370(98.5) \\
21(1.5) \\
1391\end{array}$ & $\begin{array}{c}1302(92.9) \\
99(7.1) \\
1401\end{array}$ & $<0.0001 \ddagger$ \\
\hline $\begin{array}{l}\text { How do you prepare fruit/food for eating? n (\%) } \\
\text { Washing hands before preparing } \\
\mathrm{n}\end{array}$ & $\begin{array}{c}1230(88.4) \\
1391\end{array}$ & $\begin{array}{c}1066(76.1) \\
1401\end{array}$ & $<0.0001$ \\
\hline $\begin{array}{l}\text { Have you or other household members been given any advice } \\
\text { regarding the importance of hand washing with soap? n (\%) } \\
\text { Yes } \\
\text { No } \\
\text { n }\end{array}$ & $\begin{array}{c}1161(83.5) \\
230(16.5) \\
1391\end{array}$ & $\begin{array}{c}1065(76) \\
336(24) \\
1401\end{array}$ & $<0.0001$ \\
\hline $\begin{array}{c}\text { If yes, what was the source of information?* } \mathbf{n}(\%) \\
\text { LHW } \\
\text { TV cable } \\
\text { Newspaper/Broacher/template } \\
\text { Doctor/LHV/Nurse } \\
n\end{array}$ & $\begin{array}{l}1032(88.9) \\
96(8.3) \\
22(1.9) \\
92(8.0) \\
1161\end{array}$ & $\begin{array}{c}313(29.4) \\
300(28.2) \\
55(5.2) \\
584(54.8) \\
1065\end{array}$ & \\
\hline
\end{tabular}

* represent the multiple response, $¥$ Proportions were compared using Chi-square test \& $\Psi$ Mean difference compared using Independent sample t-test

\section{Knowledge attitude practices regarding drinking water, Diarrheal disease and SODIS}

Table 2 describes the knowledge attitude and practices of the study population with regards to drinking water quality, diarrheal illnesses and SODIS. High proportion of respondents in the intervention (89\%) and control areas $(79 \%$, p value $<0.0001)$ were aware of the hazards of unsafe water and considered it to be a major risk factor for diarrhoea. Similarly most of the respondents in the intervention (90\%) and control area (78\%) had knowledge of the harmful outcomes of germs/bacteria in drinking water. Almost $91 \%$ respondentsin the intervention area had heard about SODIS method to treat water in the intervention area and LHWs were the main source of information $98 \%$. Whereas only $1 \%$ of the households in the control area heard of the intervention $82 \%$ mothers in the intervention area reported using SODIS method of water purification and $>80 \%$ used it regularly. Almost $89 \%$ of respondents were aware of the correct placement of water and exposure time (6hours) for SODIS and
81 percent were aware of the mechanism of disinfection being solar power. Majority of the population $(97 \%)$ interviewed in the intervention arm considered SODIS as an effective method to treat water for drinking The top hurdles cited for non-adherence to SODIS were prolonged process time for purification (45\%) and non-availability of PET bottles (38\%).

High proportion of respondents (96\%) believed SODIS was beneficial to their households. more than half (59\%) of the participants of intervention arm reported reduction in the diarrheal episodes following SODIS treatment of water whereas $49 \%$ reported improvement in general health of children. Majority of the household heads (96.8\%) advocated the use of SODIS for household drinking water.

\section{LHW's, SODIS intervention coverage}

The LHW coverage for the intervention (100\%) and control areas (99\%) was comparable table 3. Similarly $48 \%$ households in both the areas reported the LHW's visiting the household 
Table 2: Knowledge attitude practices regarding drinking water, Diarrheal disease and SODIS.

\begin{tabular}{|c|c|c|c|}
\hline & $\begin{array}{c}\text { Faisalabad } \\
\text { (Intervention) }\end{array}$ & Toba Tek Singh (Control) & p-value \\
\hline $\begin{array}{c}\text { *Why do young children get diarrhea? n (\%) } \\
\text { Contaminated } \\
\text { Dirty surroundings } \\
\text { Insufficient hygiene } \\
\text { Bacteria/viruses/parasites } \\
\text { Worms infestation } \\
\text { Eating mud } \\
\text { Teething } \\
\text { Change of weather } \\
\mathrm{n}\end{array}$ & $\begin{array}{c}1238(89.0) \\
752(54.1) \\
144(10.4) \\
426(30.6) \\
177(12.7) \\
241(17.3) \\
229(16.5) \\
445(32) \\
1391\end{array}$ & $\begin{array}{c}1105(78.9) \\
876(62.5) \\
48(3.4) \\
386(27.6) \\
80(5.7) \\
206(14.7) \\
271(19.3) \\
459(32.8) \\
1401\end{array}$ & $\begin{aligned}< & 0.0001 \ddagger \\
< & 0.0001 \ddagger \\
< & 0.0001 \neq \\
& 0.074 \neq \\
< & 0.0001 \neq \\
& 0.059 \ddagger \\
& 0.047 \ddagger \\
& 0.663 \ddagger\end{aligned}$ \\
\hline 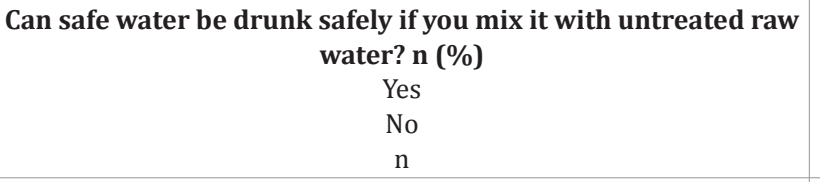 & $\begin{array}{c}129(9.3) \\
1262(90.7) \\
1391\end{array}$ & $\begin{array}{c}87(6.2) \\
1314(93.8) \\
1401\end{array}$ & $0.002 \ddagger$ \\
\hline $\begin{array}{l}\text { Do germs in the drinking water cause diarrhea and sickness? } \\
\qquad \begin{array}{c}\text { n }(\%) \\
\text { Yes } \\
\text { No } \\
\mathrm{n}\end{array}\end{array}$ & $\begin{array}{c}1252(90) \\
139(10) \\
1391\end{array}$ & $\begin{array}{c}1095(78.2) \\
306(21.8) \\
1401\end{array}$ & $<0.001 \neq$ \\
\hline $\begin{array}{l}\text { How likely is it true that untreated raw water Contains germs? } \\
\text { n (\%) } \\
\text { Slightly } \\
\text { Common } \\
\text { Very common } \\
\text { Not at all } \\
\text { Don't know } \\
\mathrm{n}\end{array}$ & $\begin{array}{c}82(5.9) \\
876(63) \\
260(18.7) \\
91(6.5) \\
82(5.9) \\
1391\end{array}$ & $\begin{array}{c}200(14.3) \\
816(58.2) \\
156(11.1) \\
7(0.5) \\
222(15.8) \\
1401\end{array}$ & \\
\hline $\begin{array}{l}\text { How likely is it true that your young children get diarrhoea } \\
\text { when they drink untreated raw water? n (\%) } \\
\text { Slightly } \\
\text { Common } \\
\text { Very common } \\
\text { Not at all } \\
\text { Don't know } \\
n\end{array}$ & $\begin{array}{c}30(2.2) \\
798(57.4) \\
328(23.6) \\
127(9.1) \\
108(7.8) \\
1391\end{array}$ & $\begin{array}{l}218(15.6) \\
672(48) \\
151(10.8) \\
113(8.1) \\
247(17.6) \\
1401\end{array}$ & \\
\hline $\begin{array}{l}\text { Have you ever heard about SODIS-method to treat water for } \\
\text { drinking? n (\%) } \\
\text { Yes } \\
\text { No } \\
\text { n }\end{array}$ & $\begin{array}{c}1260(90.6) \\
131(9.4) \\
1391\end{array}$ & $\begin{array}{c}13(0.9) \\
1388(99.1) \\
1401\end{array}$ & \\
\hline $\begin{array}{l}\text { If yes, what was the source of information?* } \mathbf{n}(\mathbf{\%}) \\
\text { LHW } \\
\text { TV cable } \\
\text { Newspaper/Broacher/template } \\
\text { Doctor } \\
n\end{array}$ & $\begin{array}{l}1232(97.8) \\
142(11.3) \\
18(1.4) \\
2(0.2) \\
1260\end{array}$ & $\begin{array}{l}4(30.8) \\
3(23.1) \\
2(15.4) \\
1(7.7) \\
13\end{array}$ & \\
\hline 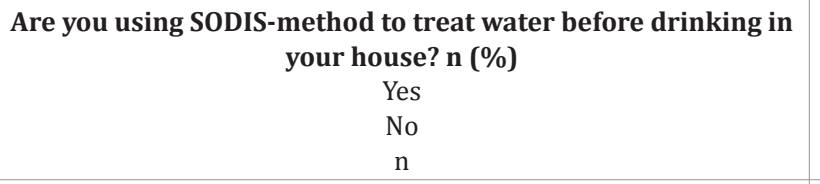 & $\begin{array}{c}1035(82.1) \\
225(17.9) \\
1260\end{array}$ & $\begin{array}{c}0(0) \\
13(100) \\
13\end{array}$ & \\
\hline 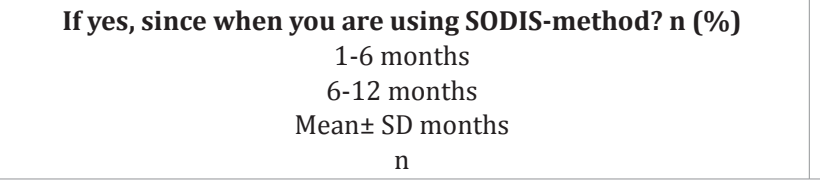 & $\begin{array}{l}668(64.5) \\
367(35.5) \\
4.33 \pm 4.55 \\
1035\end{array}$ & $\begin{array}{l}- \\
- \\
-\end{array}$ & \\
\hline
\end{tabular}




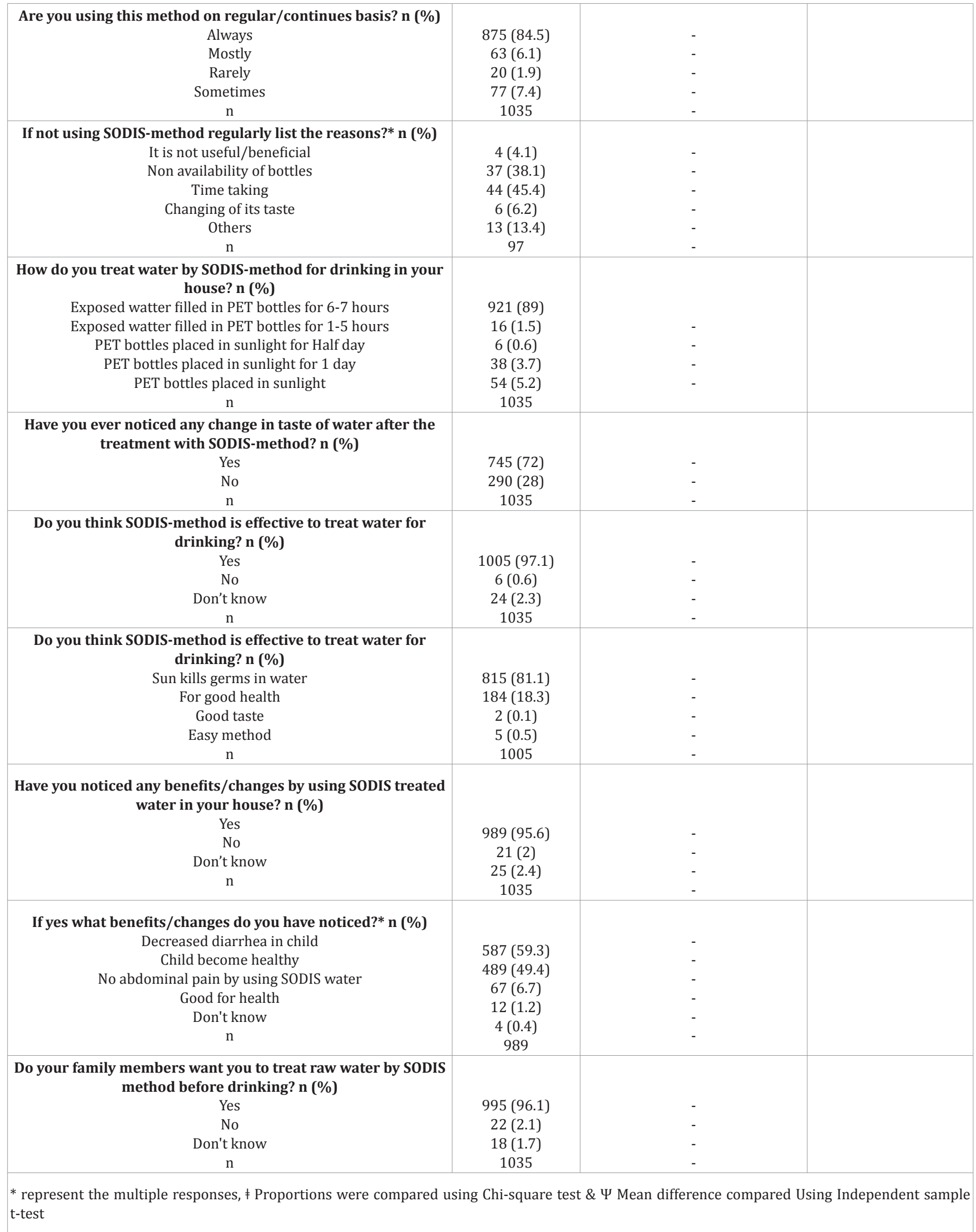




\begin{tabular}{|c|c|c|c|}
\hline & $\begin{array}{c}\text { Faisalabad (Intervention) } \\
\qquad(\mathrm{N}=1391)\end{array}$ & $\begin{array}{c}\text { Toba Tek Singh (Control) } \\
\text { (N=1401) }\end{array}$ & p-value \\
\hline $\begin{array}{c}\text { Does a LHW visit your home? n (\%) } \\
\text { Yes } \\
\text { No } \\
\text { n }\end{array}$ & $\begin{array}{c}1387(99.7) \\
4(0.3) \\
1391\end{array}$ & $\begin{array}{c}1382(98.9) \\
16(1.1) \\
1398\end{array}$ & $0.007 \ddagger$ \\
\hline $\begin{array}{l}\text { How frequently does she visit? } \mathbf{n}(\mathbf{\%}) \\
\text { Once a week } \\
\text { Once in } 15 \text { days } \\
\text { Once a month } \\
\text { Once every } 2 \text { months } \\
\text { n }\end{array}$ & $\begin{array}{l}675(48.7 \%) \\
484(34.9) \\
208(15) \\
20(1.4) \\
1387\end{array}$ & $\begin{array}{l}670(48.5) \\
453(32.8) \\
192(13.9) \\
67(4.8) \\
1382\end{array}$ & \\
\hline $\begin{array}{c}\text { *What was the purpose of the LHWs visit? n (\%) } \\
\text { General Health information } \\
\text { SODIS Information } \\
\text { Family Plannig } \\
\mathrm{n}\end{array}$ & $\begin{array}{c}1118(80.6) \\
922(66.5) \\
301(21.7) \\
1387\end{array}$ & $\begin{array}{l}358(25.9) \\
1(0.1) \\
185(13.4) \\
1382\end{array}$ & $\begin{array}{l}<0.0001 \neq \\
<0.0001 \neq \\
<0.0001 \neq\end{array}$ \\
\hline $\begin{array}{l}\text { Were you given any advice by your LHW regarding } \\
\text { SODIS-method? n (\%) } \\
\text { Yes } \\
\text { No } \\
\text { n }\end{array}$ & $\begin{array}{c}1262(91) \\
125(9) \\
1387\end{array}$ & $\begin{array}{c}18(1.3) \\
1364(98.7) \\
1382\end{array}$ & $<0.0001 \neq$ \\
\hline $\begin{array}{l}\text { In the last one month, have you received any health } \\
\text { messages on SODIS-method from the following? n (\%) } \\
\text { TV cable } \\
\text { Newspaper/broacher } \\
\text { LHW } \\
\mathrm{n}\end{array}$ & $\begin{array}{c}227(18) \\
13(1) \\
1022(81) \\
1262\end{array}$ & $\begin{array}{c}4(22.2) \\
13(72.0) \\
1(5.6) \\
18\end{array}$ & \\
\hline
\end{tabular}

* represent the multiple response, $¥$ Proportions were compared using Chi-square test \& $\Psi$ Mean difference compared using Independent sample t-test

atleast once a week. $81 \%$ percent of respondent reported having received information on health, hygiene and immunization practices in the intervention area vs. $26 \%$ percent in the nonintervention area. In the intervention area $81 \%$ respondents reported LHW's while $18 \%$ mentioned Television as the source for receiving information regarding SODIS in past 1 month.

\section{Impact of SODIS on diarrhoea in past two weeks}

Table 4 reflects that there was a significant impact of SODIS intervention on diarrheal illness in the intervention compared to non-intervention area. Diarrhoea prevalence was 10.1 episodes per child per year in the non-intervention area compared to 5.6 episodes per child per year $(\mathrm{p}<0.0001)$ in the intervention area. Similarly the proportion of children with dysentery reported in the intervention was half compared to non-intervention area (6.1\% vs. $13.9 \%)$

\section{Factors influencing incidence of diarrhoea and health impact of SODIS in under five children}

Table 5 enumerates the various risk factors affecting diarrhoea in the study area. Outcome variable is diarrhoea in last two weeks, Binary variable with coding $0=$ No diarrheal in last two weeks and 1=diarrhoea in last two weeks. By taking "0" No diarrhoea as a reference category to predict risk of having diarrhoea among various possible risk factors SODIS water treatment decreased the likelihood of diarrheal illnesses by 2 folds ( $95 \%$ CI 1.37 - 2.99) compared to non-treated water consumption. The adjusted odds of diarrheal illnesses in under five population greatly increased with the number of children in the household. Presence of more than one under five child increased the odds of diarrhoea in the past 2 weeks by 1.6 (95\% CI 1.26-2.03) compared to one under five child in the household. (Adjusted OR 0.69, 95\% CI 0.39-1.22)

Similarly adherence to hand washing practices had a protective effect [(adjusted OR 2.1) 95\% CI 1.34-3.23] from diarrheal illnesses.

\section{Discussion}

The study focused to establish the impact of SODIS to reduce diarrheal episodes and to evaluate its uptake by the community at large. The study showed a significant impact of SODIS treatment on diarrheal episodes which is similar to studies conducted in Kenya, India and Cambodia [8, 10-11].

Impact of SODIS was measured via 'reported diarrhoea' in the last two weeks; type of diarrhoea; associated symptoms (e.g. vomiting, stomach pain); and factors influencing diarrhoea (e.g. hand washing). SODIS caused a significant reduction in the number of new cases of diarrhoea and our results are supported by a similar study conducted in Kenya for duration of four months revealing 10 percent less new cases of diarrhoea in families using SODIS when compared with those who were not [8]. Another observational study also conducted in Kenya revealed a $16 \%$ 
Table 4: Diarrhea in last two weeks.

\begin{tabular}{|c|c|c|c|}
\hline & Faisalabad (Intervention) & T.T.SING (Control) & p-value \\
\hline Total Under 5 & 2213 & 2429 & \\
\hline Diarrheal prevalence (past two weeks) in under 5 (\%) & $125(5.6)$ & $245(10.1)$ & $<0.0001 \ddagger$ \\
\hline $\begin{array}{l}\text { Average diarrheal episodes- those who had diarrhea in } \\
\text { past two weeks (Mean } \pm \text { SD) }\end{array}$ & $1.92 \pm 0.89$ & $2.24 \pm 0.68$ & $<0.001 \Psi$ \\
\hline Average days of illness for last episode (Mean \pm SD) & $2.77 \pm 1.91$ & $3.33 \pm 2.48$ & $0.028 \Psi$ \\
\hline $\begin{array}{c}\text { Presence of Blood in Stool (current or last episode) } \mathbf{n} \\
\text { (\%) }\end{array}$ & $7(6.1)$ & $34(13.9)$ & $0.031 \neq$ \\
\hline
\end{tabular}

Table 5: Factors influencing diarrheal prevalence and health impact of SODIS in under age of five children.

\begin{tabular}{|c|c|c|c|c|c|c|}
\hline & \multicolumn{2}{|c|}{ Diarrhea in last 2 weeks } & \multirow{2}{*}{$\operatorname{Exp}(\beta)$} & \multirow{2}{*}{ p-value } & \multirow{2}{*}{$\operatorname{Exp}(\beta)^{* *}$} & \multirow{2}{*}{ p-value } \\
\hline & No & Yes & & & & \\
\hline $\begin{array}{c}\text { District n (\%) } \\
\text { Toba Tek Singh (Control) } \\
\text { Faisalabad (Intervention) }\end{array}$ & $\begin{array}{l}1174(48.0) \\
1271(52.0)\end{array}$ & $\begin{array}{l}227(65.4) \\
120(34.6)\end{array}$ & $\begin{array}{c}2.05(1.62-2.59) \\
\text { Ref. }\end{array}$ & $<0.0001$ & $\begin{array}{c}1.3(0.89-1.78) \\
\text { Ref. }\end{array}$ & 0.19 \\
\hline $\begin{array}{c}\text { Educational status of head of } \\
\text { household } \mathbf{n}(\%) \\
\text { Illiterate } \\
\text { Literate }\end{array}$ & $\begin{array}{c}908(37.1) \\
1537(62.9)\end{array}$ & $\begin{array}{l}150(43.2) \\
197(56.8)\end{array}$ & $\begin{array}{c}1.28(1.02-1.61) \\
\text { Ref. }\end{array}$ & 0.029 & -- & -- \\
\hline $\begin{array}{c}\text { Under } 5 \text { year children } \mathbf{n}(\%) \\
\text { More than one } \\
\text { One }\end{array}$ & $\begin{array}{l}1261(51.6) \\
1184(48.4)\end{array}$ & $\begin{array}{l}224(64.6) \\
123(35.4)\end{array}$ & $\begin{array}{c}1.71(1.35-2.16) \\
\text { Ref. }\end{array}$ & $<0.0001$ & $\begin{array}{c}1.6(1.26-2.03) \\
\text { Ref. }\end{array}$ & $<0.0001$ \\
\hline $\begin{array}{c}\text { Improved drinking water } \\
\text { No } \\
\text { Yes }\end{array}$ & $\begin{array}{c}2173(88.9) \\
272(11.1)\end{array}$ & $\begin{array}{c}304(87.6) \\
43(12.4)\end{array}$ & $0.88(0.63-1.25)$ & 0.49 & -- & -- \\
\hline $\begin{array}{c}\text { Improved toilet facility } \\
\text { No } \\
\text { Yes }\end{array}$ & $\begin{array}{c}47(1.9) \\
2398(98.1)\end{array}$ & $\begin{array}{c}8(2.3) \\
339(97.7)\end{array}$ & $1.20(0.56-2.56)$ & 0.63 & -- & -- \\
\hline $\begin{array}{c}\text { Hand washing (under } \mathbf{5} \text { year } \\
\text { children) } \mathbf{n}(\%) \\
\text { No } \\
\text { Yes }\end{array}$ & $\begin{array}{c}89(3.6) \\
2356(96.4)\end{array}$ & $\begin{array}{c}31(8.9) \\
316(91.1)\end{array}$ & $\begin{array}{c}2.6(1.70-3.97) \\
\text { Ref. }\end{array}$ & $<0.0001$ & $\begin{array}{c}2.1(1.34-3.23) \\
\text { Ref. }\end{array}$ & 0.001 \\
\hline $\begin{array}{c}\text { Using Sodis method to treat drinking } \\
\text { water } \mathbf{n}(\%) \\
\text { No } \\
\text { Yes }\end{array}$ & $\begin{array}{c}1482(60.6) \\
963(39.4)\end{array}$ & $\begin{array}{c}275(79.3) \\
72(20.7)\end{array}$ & $\begin{array}{c}2.51(1.91-3.30) \\
\text { Ref. }\end{array}$ & $<0.0001$ & $\begin{array}{c}2(1.37-2.99) \\
\text { Ref. }\end{array}$ & $<0.0001$ \\
\hline $\begin{array}{c}\text { Wealth Quintile n (\%) } \\
\text { Two Poorest } \\
\text { Three richest }\end{array}$ & $\begin{array}{c}967(39.6) \\
1478(60.4)\end{array}$ & $\begin{array}{l}150(43.2) \\
197(56.8)\end{array}$ & $\begin{array}{c}1.16(0.93-1.46) \\
\text { Ref. }\end{array}$ & 0.191 & $\begin{array}{c}1.3(1.02-1.65) \\
\text { Ref. }\end{array}$ & 0.031 \\
\hline
\end{tabular}

percent reduction of diarrhoeal illnesses in children under 5 years of age utilizing SODIS over one year [12].

The effectiveness of SODIS method was well established as $97.5 \%$ of the population using. SODIS methods were convinced of its benefits. Among those who used the SODIS method, 52.9\% reported decreased diarrhoea in children under five and $60.8 \%$ reported an improvement in general health of their children.

The overwhelming increase in compliance of the SODIS method may be attributed to the awareness of benefits of clean drinking water and lack of alternative safe water sources. The results overall are in consonance with the findings of Kevin $G$ McGuigan et al (2011) [8] where SODIS was concomitant with a $50 \%$ reduction in risk of diarrheal diseases. The aetiology of diarrhoeal disease among the survey population is not certain but subjectively determined to be the result of poor hygiene and utilization of unsafe water. This is strongly depicted ( $p$ value of 0.0006 ) among the poorest quintile of the survey population.

Analysis with regression models revealed that the four out of the seven postulated influencing factors were significant: children have a lower risk of contracting diarrhoea when they consume high percentages of safe drinks, live in households with good hygiene, wash hands, and belongs to the richest quintile. This is paralleled with Graf J et al (2008) [11] and (2010) [14].

Based on our findings, SODIS method for purifying drinking 
water is acceptable and effective in the developing countries. It is safe, cheap and convenient method. In order to reduce under five mortality, SODIS needs to be included as an intervention in the preventive strategies to control diarrheal illnesses. The community mobilization strategies were effective as majority of the respondents were either practicing SODIS or were willing to adopt it.

\section{Acknowledgement}

The authors would like to acknowledge the exceptional support provided Ministry of Health Punjab, National Program for Family Planning and Primary Health Care Government of Punjab, Pakistan. We would like to appreciate all the staff of the study for their hard work and support notably we would like to offer our sincere gratitude to the communities and local authorities in districts Faisalabad and Toba Tek Singh.

\section{Author Contributions}

All authors contributed to the project and manuscript writing. ZAB\& SBS were involved in conceptualization of the study design. SA \& AT developed the first draft. SA, UK, HA, IH, DM and TM contributed to subsequent version of manuscript. SBS as principal investigator was involved in all aspects of this study. UK\& IH implemented the study and also contributed to manuscript writing and review. SBS and SA reviewed the final manuscript. $\mathrm{ZB}$ and IA oversaw the data management and data analysis. ZAB served as a senior technical advisor and reviewed the final manuscript. All authors reviewed and approved the final manuscript.

\section{Role of the Funding Source}

The work was supported by the Swiss Agency for Development and Cooperation (SDC). The project was carried out in collaboration with the National Programme for Family Planning \& Primary Health Care, Government of Punjab and Community Action Programme. The funding body provided clearance for the project design but apart from field visits to review progress did not influence the field trial or the data analysis procedures.

\section{Competing Interests}

All authors declare that they have no conflict of interest.

\section{References}

1. Ali SM, Nasir ZM. Gains in life expectancy by elimination of specified causes of death in Pakistan. Pak Dev Rev Winter. 1988;27(4 Pt 2):645651.

2. You D, Hug L, Ejdemyr S, Idele P, Hogan D, Mathers C, et al. United Nations Inter-agency Group for Child Mortality Estimation (UN IGME) Global, regional, and national levels and trends in under-5 mortality between 1990 and 2015, with scenario-based projections to 2030: a systematic analysis by the UN Inter-agency Group for Child Mortality Estimation. Lancet. 2015;386(10010):2275-2286 DOI:org10.101 6S0140-6736(15)00120-8

3. World Health Organization: Global health risks: mortality and burden of disease attributable to selected major risks.

4. Liu L, Johnson HL, Cousens S, Perin J, Scott S, Lawn JE, et al. Child Health Epidemiology Reference Group of WHO and UNICEF. Global, regional, and national causes of child mortality: an updated systematic analysis for 2010 with time trends since 2000. Lancet. 2012;379(9832):21512161. D0I:org/10.1016/S0140-6736(12)60560-1

5. Pruss A, Kay D, Fewtrell L. Bartram J Estimating the burden of diseasefrom water, sanitation, and hygiene at a global level. Environ Health Perspect. 2002;110: 537-542.

6. Gadgil A. Drinking water in developing countries. Annu Rev Energy Environ.1998;23(1):253-286. DOI:10.1146/annurev.energy.23.1.253

7. National Institute of Population Studies, Measure DHS: Pakistan: Demographic and Health Survey 2012-13. 2013.

8. Fewtrell L, Kaufmann RB, Kay D, Enanoria W, Haller L, Colford JM Jr. Water, sanitation, and hygiene interventions to reduce diarrhoea in less developed countries: a systematic review and meta-analysis. Lancet Infect Dis. 2005;5:42-52.

9. Zwane AP, Kremer M. What works in fighting diarrheal diseases indeveloping countries? A critical review. National Bureau of Economic Research. 2007

10. Clasen T, Schmidt WP, Rabie T, Roberts I. Cairncross SInterventions toimprove water quality for preventing diarrhoea: systematic review and metaanalysis. BMJ. 2007;334(7597):782. doi:10.1136/ bmj.39118.489931.BE

11. Oates PM, Shanahan P, Polz MF. Solar disinfection (SODIS): simulation ofsolar radiation for global assessment and application for point-ofuse water treatment in Haiti. Water Res. 2003;37(1):47-54.

12. Gelover S, Gomez LA, Reyes K, Leal MT. A practical demonstration of water disinfection using TiO2 films and sunlight. Water Res. 2006; 40(17):3274-3280.

13. Sichel C, Fernandz-Ibanez P, De Cara M, Tello J. Lethal synergy of solar UV-radiation and $\mathrm{H} 2 \mathrm{O} 2$ on wild Fusariumsolani spores in distilled and natural well water. Water Res. 2009;43(7):1841-1850. doi:10.1016/j. watres.2009.01.017.

14.McGuigan KG, Joyce TM, Conroy RM, Gillespie JB, Elmore-Meegan M. Solar disinfection of drinking water contained in transparent plastic bottles: characterizing the bacterial inactivation process. J ApplMicrobiol. 1998;84:1138-1148.

15. Wegelin M, Canonica S, Mechsner K, Fleischmann T, Pesario F, Metzler A. Solar water disinfection (SODIS): Scope of the process and analysis of radiation experiments. J Water SRT-Aqua. 1994;43:154-169.

16. Joyce T, Kenny V, McGuigan K, Barnes J. Disinfection of water by sunlight. Lancet 1992;340(8824):921.

17. Christen et al. BMC Public Health. 2011;11:210.

18. Boyle M, Sichel C, Fernandez-Ibanez P, rias-Quiroz GB, Iriarte-Puna M, Mercado A, et al. Bactericidal effect of solar water disinfection under real sunlight conditions. Appl Environ Microbiol. 2008;74(10):29973001. doi:10.1128/AEM.02415-07

19. Hunter PR. Household water treatment in developing countries: comparing different intervention types using meta-regression. Environ SciTechnol. 2009;43(23):8991-8997. DOI:10.1021/ es9028217.

20.Schmidt WP, Cairncross S. Household water treatment in poor populations: is there enough evidence for scaling up now? Environ SciTechnol. 2009;43(4):986-992.

21. Mausezahl D, Christen A, Pacheco GD, Tellez FA, Iriarte M, Zapata ME et al. Solar drinking water disinfection (SODIS) to reduce childhood diarrhoea in rural Bolivia: a cluster-randomized, controlled trial. PLoS 
Med. 2009;6(8):e1000125. doi:10.1371/journal.pmed.1000125.

22. Rose A, Roy S, Abraham V, Holmgren G, George K, Balraj V, et al. Solar disinfection of water for diarrhoeal prevention in southern India. Arch Dis Child. 2006;91(2):139-141. doi:10.1136/adc.2005.077867

23. Conroy RM, Elmore-Meegan M, Joyce T, McGuigan KG, Barnes J. Solar disinfection of drinking water and diarrhoea in Maasai children: a controlled field trial. Lancet. 1996;348(9043):1695-1697.

24. Togouet SZ, Graf J, GangouePieboji J, Kemka N, Niyitegeka D, Meierhofer R. Health gains from solar water disinfection (SODIS): evaluation of a water quality intervention in Yaounde, Cameroon. J Water Health. 2010,4:779-796. doi:10.2166/wh.2010.003.

25. UNICEF and WHO. Diarrhoea: Why children are still dying and what can be done. United States of America. 2009.

26. UNICEF and WHO. Progress on drinking water and sanitation 2012 update. United States of America.2012.

27.WHO/UNICEF Joint Monitoring Programme for Water Supply and Sanitation. Water for Life: Making it Happen. Geneva. 2005.

28. UNICEF. Pneumonia and Diarrhoea - Tackling the deadliest diseases for the world's poorest children. United Nations Children's Funds. New York. 2012.

29. Biloo AG, T Ahmed. Child Survival Part II. In: M. Iliyas (ed.) Community Medicine and Public Health. Karachi, Time Traders. 1997.

30. Du Preez M, Conroy RM, Ligondo S, Hennessy J, Elmore-Meegan M, Soita A, et al. Randomized Intervention Study of Solar Disinfection of Drinking Water in the Prevention of Dysentery in Kenyan
Children Aged under 5 Years. Environmental Science \& Technology. 2011;45(21):9315-9323. doi:10.1021/es2018835.

31. Hobbins M. The SODIS health impact study (Summary Report). Basel: Swiss Tropical Institute. 2003.

32. McGuigan KG, Samaiyar P, Du Preez M, Conroy RM. High Compliance Randomized Controlled Field Trial of Solar Disinfection of Drinking Water and Its Impact on Childhood Diarrhea in Rural Cambodia. Environmental Science \& Technology. 2011;45(18):7862-7867. doi:10.1021/es201313x

33. Graf J, Meierhofer R, Wegelin M, Mosler HJ. Water disinfection and hygiene behaviour in an urban slum in Kenya: impact on childhood diarrhoea and influence of beliefs. International Journal of Environmental Health Research. 2008;18(5):335-355. doi:10.1080/09603120801966050.

34. Conroy RM, Elmore-Meegan M, Joyce T, McGuigan KG, Barnes J. Solar disinfection of water reduces diarrhoeal disease: An update. Archives of Diseases in Childhood. 1999;81(4):337-338. doi:10.1136/ adc.81.4.337

35. Rose A, Roy S, Abraham V, Holmgren G, George K, Balraj V, et al. Solar disinfection of water for diarrhoeal prevention in southern India. Archives of Disease in Childhood. 2006;91(2):139-141. doi:10.1136/ adc. 2005.077867

36. Graf J, Togouet SZ, Kemka N, Nyiytegeka D, Meierhofer R, Pieboji JG. Health gains from solar water disinfection (SODIS): evaluation of a water quality intervention in Yaoundé, Cameroon. Journal of Water and Health. 2010;8(4):779-796. doi:10.2166/wh.2010.003 